\title{
Whatever happened to second tier settlements? A survey of settlements under the Labour Relations Act 1987
}

\author{
Raymond Harbridge*
}

The Labour Relations Act 1987 provides a package that will enable employers to effectively dismantle the system of national awards should they so desire. Such employers will no doubt use the provisions of the Act that restrict unions to a single set of negotiations for any group of workers - thus effectively eliminating secondary bargaining as we have known it. This research examines what has happened to second tier settlements in the 1987/88 wage round. It is concluded that this wage round has been very much treated as a transitional round as far as wage bargaining is concerned. New rules effectively eliminating secondary bargaining have been widely ignored by unions and employers alike as both groups grapple with difficult decisions about the future of wage bargaining. Old practises have been informally continued in many industries. There is some evidence however that the maintenance of the national award system in future wage rounds will present significant problems for some unions.

Anyone confused about what the Labour Relations Act (LRA)1 was intended to achieve, should read the statement by the Minister of Labour in his foreword to A Guide to the Labour Relations Act (Department of Labour, 1987). There the Minister states that features of the $L R A$ reflect the rise of negotiation and the decline of compulsory conciliation and arbitration. The Minister however correctly points out that changes to the legislation will not automatically alter the behaviour of labour relations participants

* Industrial Relations Group, Victoria University of Wellington. He wishes to thank Stuart McCaw for research assistance. This research was supported by grant 23/88 of Victoria University's Internal Research Committee. This paper was prepared in April 1988 and surveys settlements reached at that point in time.

1 Throughout this paper the term "settlement" is a generic term for a settlement of an interest dispute between an employer and a union. A "document" is a written formal settlement. An "award" is an award reached under Part VII of the Labour Relations Act (LRA) or registered under Section 82 or 84 of the Industrial Relations Act (IRA). An "agreement" is an agreement registered under Section 164 of $L R A$. A "VCA" is a voluntary collective agreement registered under Section 64 of the IRA. A "COA" is a composite agreement registered under Section 166 of LRA or Section 66 of IRA. A "composite award" is a composite award registered under Section 137 of LRA. 
and that the process of change away from compulsory conciliation and arbitration will be a slow one.

The New Zealand Business Roundtable are less coy about what the "rise of negotiation" means - along with the speed with which that rise will occur. In a recent briefing paper, they state -

\begin{abstract}
The central idea of the architects of the bill was that, rather than challenge the role of the national awards and blanket coverage directly, a preferable approach was to provide options which would lead to their progressive contraction. This could be orchestrated by an employer strategy which concentrated on holding broadly based awards down to standard levels, while offering (by informal communication) the prospect of better deals on an industry/enterprise basis where these could be afforded.
\end{abstract}

(New Zealand Business Roundtable, 1988, p3)

There are a number of provisions in the $L R A$ that will lead to the diminishing in importance of the national award system. These include first the retention of the voluntary arbitration provisions first introduced in 1984 - this enables a group of determined employers' assessors to frustrate the negotiation process by declining to accept any union claims and (ultimately) forcing a particular award to lapse. This was introduced with tripartite agreement in the euphoria immediately after Labour's election in 1984. However last year Federation of Labour Secretary Ken Douglas was critical of the LRA because it did not offer an effective means for dispute resolution because it relied on voluntary rather than compulsory arbitration (Douglas quoted in Pearson, 1987).

The second provision is the (albeit limited) right of unions to contest each other's coverage. The third is the effective abolition of second tier bargaining. The Government has chosen at this stage not to re-introduce voluntary unionism but that is a logical extension of the package implemented last year and it would be no surprise to me to see it introduced in the future - maybe even in the run-up to the next election.

The package as it stands in the $L R A$ is one that enables employers to take apart the national award system but it requires an employer initiative to achieve that and as the New Zealand Business Roundtable point out there is plenty of evidence in this year's wage round that a substantial number of employers are sufficiently inert so as to frustrate any such attempt by the innovative employers (New Zealand Business Roundtable, 1988, p4).

The question of second tier bargaining is of pivotal importance in understanding the future directions of wage bargaining for it is here that the battle for the maintenance of the national award system will be fought in the short term. The tiered system of bargaining that emerged in New Zealand has the retention of a "floor" award - effectively a lowest common denominator approach to setting minimum wage and condition levels with unions seeking top-up payments in industries and occupations where they could be achieved and afforded.

Many fail to realise just how minimal the national award levels have been - at the start of the 1986/87 wage round there were 39 awards containing adult rates of pay below the $\$ 210$ per week statutory minimum wage introduced part way through that wage round. At the start of the 1987/88 wage round there were 17 awards containing rates of pay below the $\$ 225$ per week statutory minimum wage introduced in February 1988 . That so many awards provide such minimal rates is surprising but it is indicative of the generally low rates that unions negotiate. Taking the Government's minimum wage of $\$ 225$ per week as a "rock bottom" standard, there were 38 awards at the beginning of this wage round containing adult rates less than $\$ 240$ per week. In arguing for the protection of the national award system many unionists seem oblivious to the obvious failure of that system to provide adequate living incomes.

In 1985 I undertook a study of collective second tier bargaining in New Zealand (Harbridge, 1986). I identified a comparatively small number of unions that used secondary bargaining and concluded that (after the peculiar activities of the NZ 
Meatworkers Union were excluded from the study) around six percent of the work-force was a beneficiary of a union negotiated secondary arrangement. I further concluded that the so-called national award system was the major (and often sole) contributor to most worker's pay packets - a view supported by the New Zealand Planning Council's Economic Monitoring Group (Economic Monitoring Group, 1986).

Second tier bargaining as we knew it was effectively abolished by the $L R A$. Section 132(a) of the LRA states that a general object of the legislation is to establish that the terms and conditions relating to employment of groups of workers are fixed by a single set of negotiations. Employers now have the right to be bargained with just once for any group of workers. The union has the choice as to whether the employer will be covered by the main award or by a separate agreement. If the union determines the employer should be covered by the terms of the award and subsequently asks that employer for further negotiations then the resulting settlement cannot be registered with the Arbitration Commission (and thus cannot be enforced). Further the settlement enables the employer to go to the Labour Court under Section 152 of the LRA and ask for an exemption from the award. If an employer succeeds in seeking award exemption or becomes party to a separate agreement, then the employer and union must both agree before that employer can be bound by any subsequent award. In other words decisions made in the 1987/88 wage round about the structure of bargaining will, in many cases, be irreversible.

A further problem for unions exists over the possible use of Section 152 of the Act. Currently the $L R A$ contains provisions allowing the negotiation of compulsory union membership clauses into settlements. Where an employer successfully applied for an award exemption, that exemption would be from union membership as well - a point the Wellington Regional Employers Association made to its members when reviewing the changes (Wellington Regional Employers Association, 1987). The loss of union membership provisions in this way would mean unions had a very difficult path to tread to re-enter bargaining with that employer. Further, as no award covering such a group of workers will exist, provisional registration may be given to a new or alternative union.

The difficulty posed for unions by the "single set of negotiations" provision has been how to achieve realistic settlements for their members who expect a second tier top-up while preventing the national award from being eroded. Unions that had previously negotiated a wide range of formal and informal second tier arrangements with their "better" employers can continue to do that - except those arrangements will take those employers out of the parent award. This will have the almost certain effect of weakening the union's ability to negotiate a satisfactory award settlement as the union will be dealing with the "worse" employers in the industry. "Better" employers and second tier arrangements have been traditionally used to boost increments in the national award settlements - that possibility is now gone.

The dilemmas that unions faced over their secondary bargaining can be resolved. I think there are seven realistic options that unions can exercise - some of these are spelt out in a NZ Federation of Labour Circular to affiliates (New Zealand Federation of Labour, 1987). First, they can enter into separate agreements under Section 164 of the $L R A$. As I've indicated the difficulty for unions here is that the removal of such employers from the national award can significantly weaken the union's ability to satisfactorily negotiate that award.

Second, the union can enter into composite agreements with other unions and the same employer under Section 166 of the $L R A$. Whereas employers party to separate agreements can remain outside award coverage by their own decision, employers party to composite agreements can be brought back into the coverage of an award at the union's initiation - a significant advantage for unions seeking to protect award standards and an option that was clearly to be favoured.

Third, unions can enter into composite awards under Section 137 of the LRA. I believe that there was no legislative barrier to composite awards under the defunct Industrial Relations Act 1973, however no unions or employers had exercised this as an 
option in the past. The difficulty with it now as an option is that as only one award can apply at a time to an employer, the unions seeking a composite award must first negotiate an exemption in the parent awards. This exemption may be difficult to achieve - it may also be difficult to remove should the unions wish to do so in the future.

Fourth, unions could "codify" existing voluntary collective agreements (VCAs) and other stand-alone settlements into their main awards. By "codify" is meant keeping the employer as party to the award but having a provision within the body of award which refers to specific benefits that the employer will pay. Such a provision would need to be in the body of the award - before the term clause if the provision is to be enforceable. Many unions talked about adopting this strategy before this wage round just as many employers talked about resisting the strategy.

Fifth, unions and employers could agree to informal pass-on arrangements that would give workers receiving above award benefits, the additional percentage movement in the award rate. The main difficulty with this type of arrangement is that it would be by memorandum after the term clause of the award and as a result it would not be legally enforceable. A legally enforceable pass-on provision would be one included in the body of the award. The Arbitration Commission would register such a document as long as the pass-on provided a specific formula for calculating the increment so that the provision could not be seen as "permissive" and thus against the provisions of Section 132 of the $L R A$ which embodies the concept of a "single set of negotiations".

Sixth, unions could simply enter into "handshake" arrangements with employers over informal secondary bargaining - i.e. reach agreement over the level of the informal second tier and that the employer would not use Section 152 of the LRA to seek award exemption. The risks for the union party following this course of action speak for themselves.

Finally, the union can choose to ignore its members who are currently recipients of second tier arrangements and simply re-negotiate their award. The new found right of union members to change union coverage under Part IV of the $L R A$ would be quickly tested should any union choose that course.

The choices for unions then are limited - the most preferred options would be composite agreement and codifying. The purpose of this paper is to examine which of the options unions have chosen. The difficulty encountered in attempting to establish those choices has primarily been that many unions are some distance from completing their negotiations for this wage round and general patterns only are observable.

The activities of that small group of unions traditionally involved in secondary bargaining is interesting and for the purposes of this seminar I have reviewed the approaches they have taken to handling their second tier arrangements. The approaches reported in this paper are largely based on anecdotal evidence as comparatively few settlements have been registered by the Arbitration Commission. A summary of the various options chosen by unions according to union type is in Figure 1.

The following brief statements refer to bargaining approaches by union category.

\section{Airline stewards}

Previously this union had negotiated a small number of awards, each with only one employer party. The union's strategy in this wage round was to negotiate just one award for flight attendants. That award would cover all employers - Air New Zealand, Ansett New Zealand, and Mount Cook Airlines. These employers rejected this strategy though Air New Zealand was interested in it. This approach resulted in the negotiation of only 
畧

$z$
z
a

家

圈余

为面

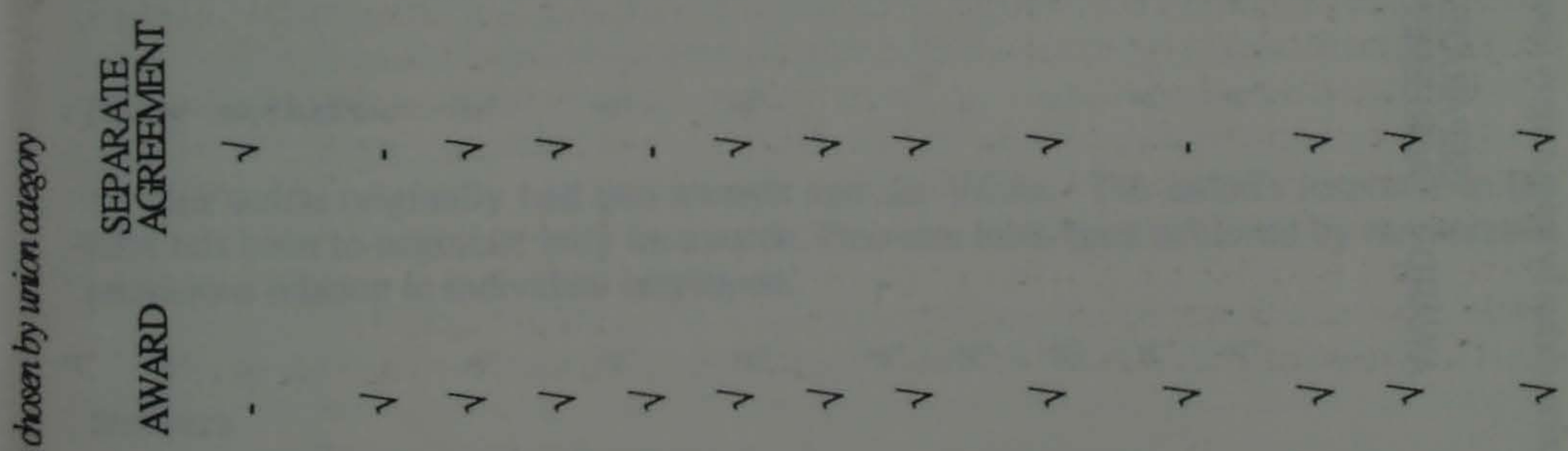

है

,

.

,,$\quad>>, \quad>>>$

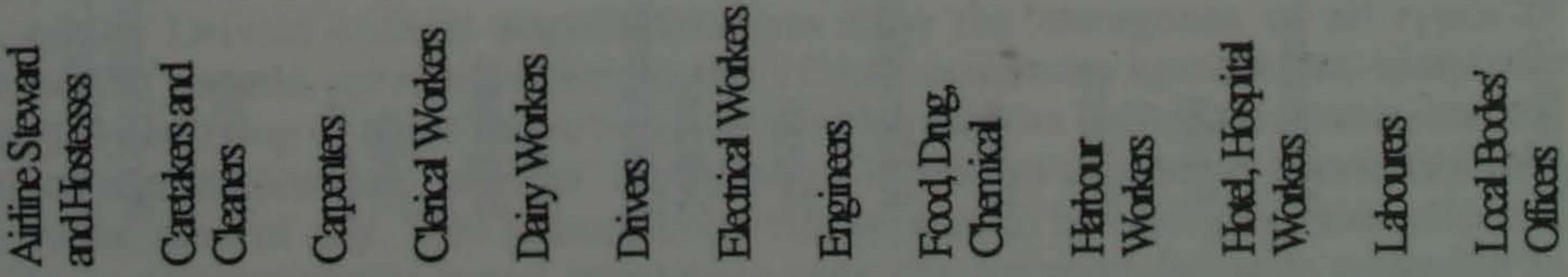


空

$z$
z్
a

$\frac{0}{8}$

井

园圆

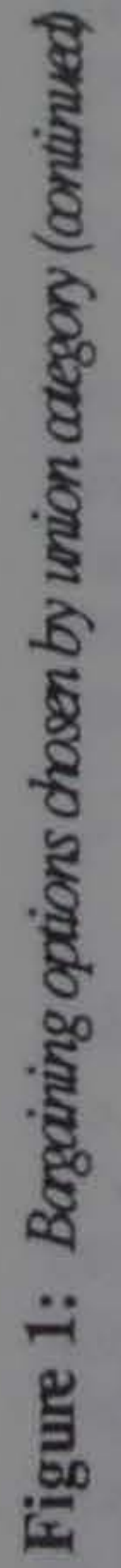

㩆夌

$>>>>>>>>>>$

$>>>>>$

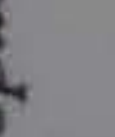

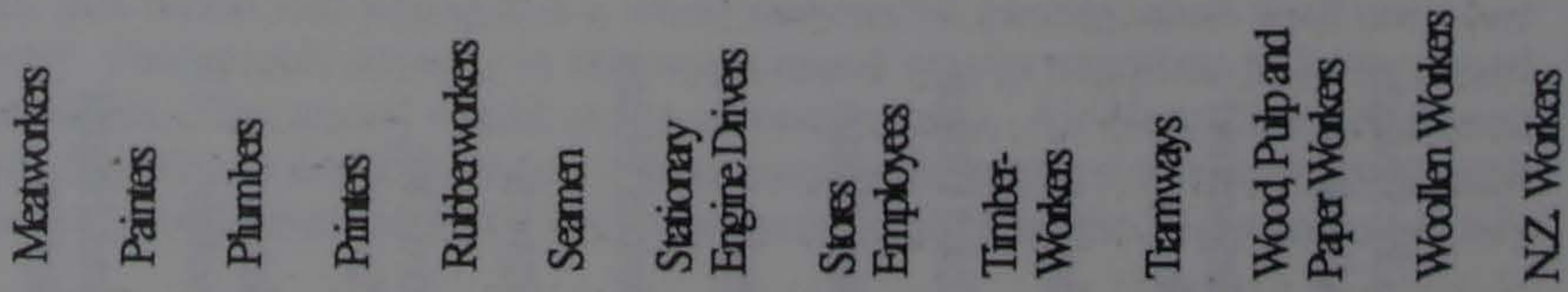


separate agreements, without a 'parent' award. Apart from this, the union indicated that there were no significant problems in negotiating this round.

\section{Caretakers and cleaners}

This union had previously been party to a number of VCAs and COAs but they had covered few workers - around 600 . The union in this round has re-negotiated its awards and its composite agreements, but to date the VCAs have not been re-negotiated and it seems possible that these employers may be brought into the main awards, but in the interim, the unions and employers have agreed to simply preserve existing arrangements through a handshake.

\section{Carpenters}

The Carpenters Union (recently renamed the Building Workers Union) had previously negotiated a prolific number of composite agreements in addition to their five awards. In this wage round their awards have been satisfactorily re-negotiated, as have these composite agreements - the small number of VCAs in existence have been re-negotiated as composite agreements.

\section{Clerical workers}

This group of unions has re-negotiated its awards and composite agreements as in the past. Many of the VCAs previously registered were one-off settlements relating to union membership and union fee deduction provisions. These have been abandoned. A small number of the remaining VCAs have been re-negotiated as agreements. Others have been allowed to lapse. The union decided to nominate for separate negotiations a number of local body employers in the South Island, thus exempting these employers from the main clerical award. However, the planned separate negotiations have not as yet taken place.

\section{Dairy workers}

This union originally had two awards and six VCAs. The union's response to the LRA has been to negotiate only its awards. Pass-ons have been achieved by memoranda provisions relating to individual employers.

\section{Drivers}

This union has had a significant number of its members covered by second tier agreements in the past. The main award has been broken into a variety of smaller, industry specific awards (the full details of which are yet to be settled). The apparent result of the Drivers Unions negotiations has been the emergence of all types of settlements - awards, agreements (replacing VCAs), composite agreements, composite awards, the codifying of some above award provisions into the individual awards, and the writing of memoranda that "pass-on" a percentage increment to workers previously paid above award rates of pay. The general trend that appears to be emerging here reflects a move from occupationally based bargaining over the transport industry generally to bargaining based on specific sub-industries. One interesting variable in this group has been the activities of the Drivers in the Northern labour district. There the union has filed 
for a regional award, effectively breaking its links with the national award. While that issue is not as yet settled it would appear that the move to develop regional rates for drivers in the north that are higher than those paid in the south is continuing. Previously this was achieved within the structure of the New Zealand General Drivers Award, Document 201. Here drivers received an industry allowance through the provisions of Clause 27 which assumes that the allowance will be different in different geographical areas of New Zealand.

\section{Electrical workers}

As with many of the trades unions, the electrical workers union has had a proliferation of second tier bargaining both formal and informal. The union has re-negotiated its awards and composite agreements. The union's formal VCAs (stand alone agreements) are either being negotiated as separate agreements (which the union describes as "modern" rather than "new" forms of settlement) or as composite agreements. Employers that have previously been exempted from the parent awards have been cited out for separate negotiations. Informal second tier arrangements have remained informal with an understanding with the employer that the employer will not seek award exemption using Section 152 of the LRA.

\section{Engineering unions}

Again this group of unions has been a prolific user of secondary bargaining. The awards and composite agreements have all been re-negotiated. The VCAs have either been negotiated as agreements or their terms have been incorporated into the awards by using either a pass-on mechanism or by codifying those terms. There appears to be an extensive informal second tier still in existence despite the risk that this strategy allows as employers may seek award exemption using Section 152 of the LRA. It is worth commenting that while this union has been credited with making significant changes to their bargaining, they have in fact, adopted a status-quo approach for this wage round while at the same time signalling their general intention of reforming their bargaining along industry lines, using the heads of agreement approach. The establishment of a working party to examine an award for the plastics industry has been a significant move that has attracted much attention from employers and unionists alike. The union's approach to the changes in bargaining have been set out in a detailed publication (New Zealand Engineering Union, 1987).

\section{Food, drug and chemical workers}

The awards have been re-negotiated (with the single party award becoming an agreement). The majority of the VCAs are being negotiated as separate agreements though one has been incorporated into an award by a pass-on mechanism. The union claims to have between 50 and 100 informal second tier settlements and these have been absorbed by the pass-on memorandum in the award.

\section{Harbour workers}

This union had three awards, one major one. It also had a wide proliferation of second tier arrangements port by port. These arrangements presented the union with a significant problem as it was felt there could be some attempt by the employers to break up the 
national award and have individual port awards. In the event, the union was able to renegotiate the main award - codifying into it the different arrangements at each port on a port by port basis. In addition there is a memorandum to the award stating that employers will conform with all other uncodified previous arrangements. The result of course, looks like the Yellow Pages of the Auckland Telephone Directory - having gone from 70 odd pages to over 300 ! The one tug composite agreement existing before the $L R A$ took effect has been codified into the main award.

\section{Hotel and hospital workers}

This group of unions had traditionally taken little interest in second tier arrangements but since 1985 has made a concerted effort to attract secondary payments for its members particularly in the industrial cafeteria area. In this wage round they have re-negotiated their awards (one, which was a single employer settlement, has become an agreement). A small number of VCAs have not been re-negotiated but have received an un-registered pass-on. The unions are likely to move to composite bargaining with other unions covering the industrial cafeteria staff industry by industry. Although to date little of this has taken place, it appears to be the likely trend.

\section{Labourers}

In November 1985 these unions had some 21 awards, 48 current VCAs and 38 current COAs, with somewhere around 5,000 workers covered by registered second tier agreements. To date the majority of the awards have been re-negotiated, and one award has been negotiated as a composite award - the Nursery workers, gardeners and landscape workers composite award. (The other union party to this award is the shop employees affiliate of the Distribution Workers Federation). Many of the composite agreements have been re-negotiated with three new ones being entered into. Many of the VCAs have deliberately not been re-negotiated as only 4 agreements have been settled at this point. These 4 agreements resulted from those employers being nominated for separate negotiations as a result of their refusal to agree to pass-on any increase in the main awards. Where VCAs have not been re-negotiated there seems to be a commitment to pass-on increments.

\section{Local body officers}

In the local authority area there has not been a national award structure for local body officers. In the northern labour district there has been the Northern Industrial District Local Government Officers' Award - Document 92. In addition, there has been a proliferation of one employer awards, and VCAs with individual local authorities. The union has attempted to preserve its existing second tier structure, by nominating for separate negotiations those employers currently paying substantially better conditions than those found in the regional award.

Local authority unions appear to have had more difficulty with their negotiations than most other groups. The northern union has attempted first to enter into some composite agreements with individual local authorities, but this has been firmly rejected by the employer concerned in favour of individual agreements. Second, the union appears to have had difficulty over its coverage clauses which have been contested by employers wishing to totally localise wage rates. (The issue of employers contesting the coverage clause of an agreement or award is a significant one which is likely to be an important mechanism for the destroying of a particular national award). 


\section{Meatworkers}

The Meatworkers Union has had a tradition of second tier bargaining that has totally emasculated their national award, to the extent where one of their officials claimed two years ago that the award would contribute only one third of the pay that the majority of meatworkers receive - the rest coming from a variety of second tier agreements. The difficulty for this union was to negotiate a true national award that contained this plethora of (in most cases) un-registered second tier agreements. To date they have failed totally in their efforts to renegotiate their award with the employers representatives remaining firm that only individual company agreements would be settled.

\section{Painters}

This union has had any number of organisational difficulties over the last few years with the Registrar of Unions threatening their registration at one point - however they had a tradition of joining into composite agreements with other unions, particularly on the large industrial sites where comparatively small numbers of painters were employed. In the 1987/88 wage round, the union has re-negotiated its awards; has re-negotiated its five VCAs as either separate agreements or composite agreements; has re-negotiated some 27 informal secondary arrangements mainly as composite agreements; has re-negotiated about 10 composite agreements and is in the process of negotiating a composite award at Kinleith.

\section{Plumbers}

The Plumbers Union had allowed its national award to lapse in the mid 80 s and relied on an extensive tier of VCAs and COAs negotiated with individual employers. The national award has been re-negotiated and restructured so that coverage extends to contractors only. The union hopes to negotiate a national award for maintenance workers but has not done so at this point. Existing VCAs have largely been re-negotiated as agreements and COAs are also in the process of being re-negotiated.

\section{Printers}

This union has had a high degree of internal autonomy with individual chapels playing a negotiating role with individual employers. Generally such negotiations have been outside the auspices of the union's national office. Clearly this union was faced with major difficulties following the introduction of the $L R A$ as these secondary arrangements potentially allowed the individual employers to be exempt from the award.

The union has had great difficulties in this round. They have, for this year anyway, renegotiated their awards; they have totally avoided having any separate agreements at this point and have informal arrangements with the three employers party to the existing VCAs - the future of which will be determined during the forthcoming year.

\section{Rubber workers}

Secondary arrangements have been very wide-spread in this small industry. Historically, the union has settled three awards and five VCAs. A significant raft of 
informal arrangements has also existed. This posed an interesting problem for the union which resolved it by asking the industry's employers to sign a form letter in which the company agreed that following the award settlement it would initiate a review of its various house arrangements with the union. The effect of the company initiating such negotiations is of course to preclude the possibility of the company seeking an award exemption under Section 152 of the $L R A$. It is interesting of course that the various companies involved were willing to enter into such an agreement.

\section{Seamen}

The union has no second tier bargaining at all now - it renegotiates only awards. The structure of the award is itself interesting however, as it contains a set of separate conditions for different vessels - thus this award is a fore-runner to the "codifying" approach being attempted by other unions in this wage round. The union has agreed to look at more composite bargaining with other seafaring unions and the union is currently examining the possibility of amalgamating with the Cooks and Stewards Union.

\section{Stationary engine drivers}

This union has had an award that has been totally superseded by second tier arrangements - formal and informal. In this wage round the union has not yet finalised its main award, it has cited out for separate agreements all the major employers and has settled a number of agreements. They are currently negotiating 4 composite agreements with other trades based unions. While the union has no deliberate policy of moving towards composite bargaining, this is seen by them as the desirable way to proceed.

\section{Stores employees}

The Northern Stores Union has undertaken much informal secondary bargaining over the last few years. Previously the union had some 14 awards, 13 VCAs and 27 COAs. To date they have negotiated seven awards. Some of the VCAs have been re-negotiated as agreements, but the union has expressed a preference for composite agreements or composite awards. About 20 composite agreements have already been settled. No composite awards have been agreed in this round though that is the union's preferred option and is likely for the future. The informal pass-on arrangements have continued though the union is well aware of the fragility of this type of arrangement and is concerned that the pass-on generally refers only to wage rather than condition matters.

\section{Timberworkers}

The union has re-negotiated its one national award. The seven VCAs are being renegotiated and/or split into either composite awards, composite agreements or agreements. The union expects the result to be two composite awards, six composite agreements, and two agreements.

\section{Tramways}

Previously this union negotiated one award and one VCA. This union has an unusual membership rule which restricts coverage to bus drivers employed by six local authorities. 
The award was a cited party award with these employers, so it contained no blanket coverage provision and further it contained regional allowances that effectively meant the award did not provide a "national rate". In this wage round, that award has been broken into 6 separate agreements each with one employer. The 6 agreements were settled at different wage increments - Auckland at 14 percent (but for two years), Wellington for 11.5 percent for one year, and the other districts for 7 percent. The two year term of the Auckland settlement is the only long term document observed in this study. The union is interested in composite bargaining with other local authority unions but has not been successful in undertaking this in this wage round.

\section{Woodpulp and paper workers}

Previously, this union has negotiated neither awards nor composite agreements - only VCAs. Under the $L R A$ the union has, to date, negotiated a composite award, a composite agreement and an agreement. There is a definite movement towards composite bargaining (encompassing not just the trades groups but also the service groups), and also a trend to site or enterprise bargaining.

\section{Woollen workers}

The main awards in this industry contain provisions that recognize individually negotiated bonus arrangements which would appear to be outside the provisions now in the $L R A$ in terms of un-registered second tier bargaining. The union appears to have ignored this problem and has simply arranged pass-on settlements. The union has successfully re-negotiated its three awards. The union has negotiated separate agreements with those employers who were previously party to VCAs.

\section{Workers}

The union has re-negotiated its five awards, and its six VCAs as agreements. A passon clause has been written into one of the awards, and it appears that some informal settlements are still being reached.

\section{Trends}

In the process of talking to unions and employers about the $1987 / 88$ wage round and their strategies for handling secondary bargaining issues, a number of trends have emerged.

First, a prerequisite for a union determining what to do about its second tier bargaining is for it to know what its second tier settlements were. This is not a facetious comment it is clear to me that the primary cause of difficulties for many unions during the $1987 / 88$ wage round has been that they had little idea of the nature, type and location of second tier arrangements that had previously been entered into on their behalf. Some unions have recognised that if they were to adhere to the "single set of negotiations" principle then they had to discover and uncover all existing tiered settlements. An example of a union that has successfully achieved this is the NZ Harbours Union. An example of a union that still has not achieved this and as a result continues to try to negotiate a settlement allowing for more than one set of negotiations is the NZ Meatworkers Union. The results of these two unions negotiations reported above speak for themselves.

Second, there is a very definite trend for unions to select composite bargaining as a technique to resolve their difficulties with their second tier. In some cases employers have 
resisted composite bargaining as an approach. The reasons for unions choosing composite bargaining are two-fold. First, as mentioned earlier, it allows the union the option of bringing the employer back into the parent award at some consequent point. Second, it allows unions to retain coverage of groups of workers on a craft basis while at the same time accepting an employer's desire for enterprise and/or industry bargaining. Unions remain allowed to organise on either craft or industry lines under the $L R A$ and composite bargaining will serve to perpetuate craft unionism which will remain frustrating for employers committed to industry bargaining.

Third, many unions have negotiated legally unenforceable pass-on memoranda to their awards. While these pass-on provisions are technically unenforceable, employers appear to be adhering to the intent of the settlement and are indeed passing-on increments to above award workers. Despite a number of attempts to do so, no union has successfully negotiated an enforceable specific pass-on provision within the body of their settlement. That employers have been willing to pass-on is largely a widespread acceptance that the implementation of bargaining changes will be a slow and negotiated process rather than one imposed by an aggressive employer stance.

Fourth, VCAs or COAs that have been "stand alone" settlements - relatively independent of the national award system - in the past, have generally been taken out of the award system and the settlements have been negotiated as agreements or COAs. A good number of VCAs have been negotiated as COAs. The removal of these employers from the awards system reflects an acceptance by the parties of the reality of the new situation - that it isn't possible to have tiered bargaining and that enterprise bargaining is inevitable in many situations.

Fifth, this round has been treated very much as a transitional round from the old to the new system - a promise of things to come. This is reflected in the widespread practice of accepting "handshakes" on secondary arrangements and establishing working parties that will meet during the currency of the document to formulate strategies for the next wage round. While such approaches have been relatively common, I feel that comparatively little has been achieved by the various working parties at this stage - in many cases the working party strategy was an excellent technique to avoid having to make difficult decisions in this wage round, but once away from the bargaining table, unions and employers have shown little enthusiasm for grappling with the "hard" decisions and it would not be surprising if the working parties have little to report to next year's wage talks.

Shortly after the passing of $L R A$, Douglas Myers, deputy chairman of the New Zealand Business Roundtable, denounced the changes to the law stating they didn't offer employers the flexibility they required. To achieve flexibility they had to contend with compulsory unionism and blanket coverage awards and they had to set out to frustrate the process of award bargaining. It would be a slow process and Myers argued that immediate and radical reform was required. That employers and unions have largely settled for the status-quo in this wage round indicates that employers (with whom the initative for change rests under $L R A$ ) are either inert as has been claimed or they are relatively content with the existing system. Both the Minister of Labour and Myers (though from different perspectives) were correct in asserting that changes to wage bargaining would be only slowly effected.

\section{References}

Department of Labour (1987) A guide to the Labour Relations Act Department of Labour, Wellington.

Economic Monitoring Group (1986) Labour market flexibility New Zealand Planning Council, Wellington. 
Harbridge, Raymond (1986) Collective second tier bargaining in New Zealand New Zealand journal of business 8:40 - 55 .

Myers, Douglas (1987) Labour market reform: getting it right New Zealand Business Roundtable, Auckland.

New Zealand Business Roundtable (1988) Labour market adjustment: assessment of the Labour Relations Act Unpublished paper, New Zealand Business Roundtable, Auckland.

New Zealand Engineering Union (1987) Strategies for change : representing workers in a new environment New Zealand Engineering Union, Wellington.

New Zealand Federation of Labour (1987) The wage round: bargaining options and strategies Circular 1987/22, New Zealand Federation of Labour, Wellington.

Pearson, Michael (1987) The fight over labour market reform Management 34 (6):30 42.

Wellington Regional Employers Association (1987) The new Labour Relations Act 1987 Circular 5.1.21, Wellington Regional Employers Association, Wellington. 